\title{
Laboratory Experiments of Slab Break-off and Slab Dip Reversal: Insight into the Alpine Oligocene Reorganization
}

Vincent Regard $^{1,2 *}$, Claudio Faccenna ${ }^{3}$, Olivier Bellier ${ }^{2}$, Joseph Martinod ${ }^{1}$

${ }^{1}$ LMTG-Université de Toulouse-CNRS-IRD-OMP, 14 av. E. Belin, 31400 Toulouse, France

${ }^{2}$ CEREGE, UMR CNRS 6635, Université Aix-Marseille III, Europôle de l’Arbois, 13545 Aix-en-Provence cedex 4, France.

${ }^{3}$ Dipartimiento di Scienze Geologiche, Università Roma tre, Largo S. L. Murialdo 1, 00146, Roma, Italy

* Corresponding author. E-mail: regard@lmtg.obs-mip.fr - Tel.: +33 561332645 - Fax: +33 561332560

\section{Running title: Slab break-off and the Alpine reorganization}

\begin{abstract}
We present laboratory experiments to study the consequence of the rupture of a subducting slab on the deep geometry of the subduction zone. In our experiments, slab break-off occurs after the entrance of buoyant material at trench causing a slowing down of the subduction, and producing an increase of the shortening rate and a transient episode of subduction dip reversal. We discuss the potential application of these processes to the recent collisional evolution of the Alps proposing that the rupture of the slab produced a re-organisation of the belt with a transition from one sided to a doubly vergent orogen.
\end{abstract}

\section{Introduction}

The occurrence of break-off processes, i.e. detachment of the deeper portion of a slab, has been proposed as an efficient mechanism to explain dramatic changes in mountain building evolution and/or upper plate tectonic re-organization. Slab discontinuity in the WadatiBenioff or high velocity zone correlated with rapid uplift of the upper plate, strain vs. stress change, pulses of volcanism and heating has been usually related to slab break-off (e.g. New Hebrides, (Châtelain et al., 1992); Apennines, (Wortel and Spakman, 1992; Buiter et al., 1998); Central America, (Rogers et al., 2002); Anatolia, (Keskin, 2003; Faccenna et al., 
2006)). Eventually, slab break-off is a rapid and efficient mechanism for subduction cessation (Davies and von Blanckenburg, 1995).

Numerical (e.g., Faccenda et al.; Chemenda et al., 1995; e.g., Davies and von Blanckenburg, 1995; Chemenda et al., 1996; Wong A Ton and Wortel, 1997; Pysklywec et al., 2000; Pysklywec, 2001; Li et al., 2002; Regard et al., 2003; Gerya et al., 2004; Toussaint et al., 2004; Regard et al., 2005) and analogue experiments (Chemenda et al., 1995, Regard et al., 2003) constrain the thermal and mechanical conditions for slab rupture, underlining the importance of rheological conditions and buoyancy forces on subducting plate behavior In this paper we analyze, using laboratory experiments, the causes and consequences of slab break-off. These experiments suggest that the rupture of the slab at depth may be accompanied by a transient episode of dip reversal. We explore the possible application of this mechanism to the Late Cenozoic Alpine orogen.

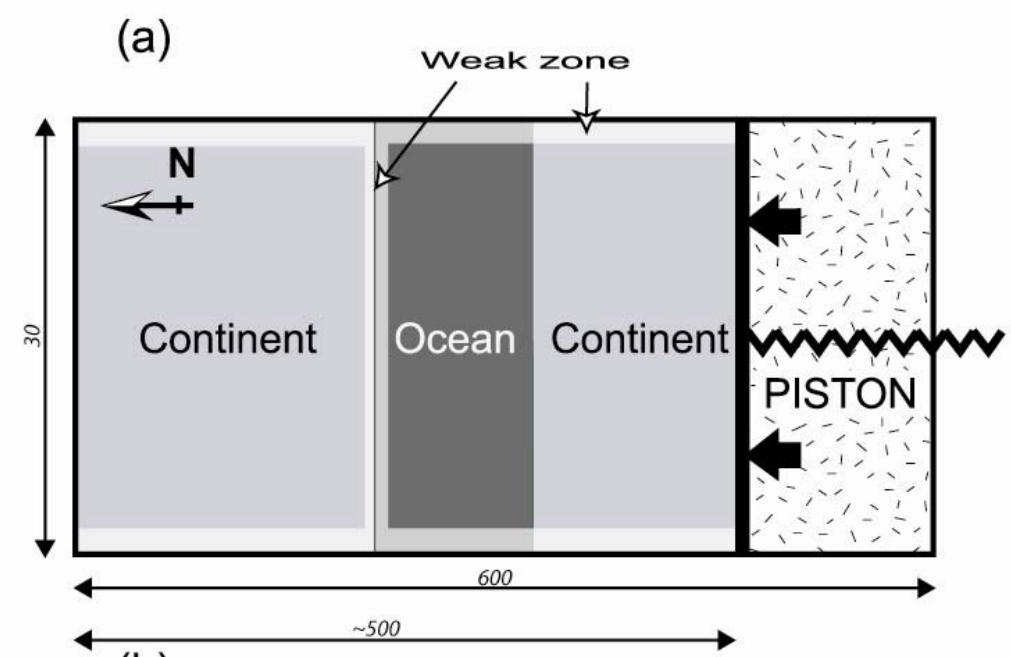

(b)

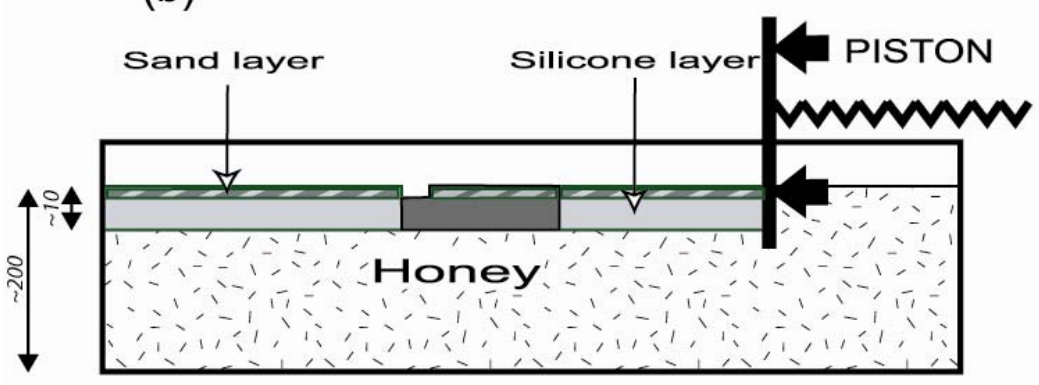

Regard et al. fig 1

Figure 1. Experimental set up. Sand/silicone plates modelling the lithosphere are lying above honey that represents the upper mantle. Lengths are in millimeters.

\section{Laboratory experiments}


Chemenda (1995) first performed experiments with continental subduction followed by break-off. Chemenda's (1995) experiments were mainly addressed to explore the way a brittle-plastic slab breaks. Here we extend this study to the case of a visco-plastic rheology. We performed a set of experiments to analyze the style of deformation during and after slab break-off. Hence, our experiments are expressively constructed to model the late stage of subduction and collision, while a complete analysis of continental subduction and slab deformation is presented in Regard et al. (2003).

Table 1: Scaling factors for the experiments

\begin{tabular}{|c|c|c|c|c|}
\hline Quantity & $\begin{array}{l}\text { Symbol } \\
\text { (unit) }\end{array}$ & Nature & Model & $\begin{array}{l}\text { Scaling ratio } \\
\text { Model/nature }\end{array}$ \\
\hline \multicolumn{5}{|c|}{ Controlling parameters } \\
\hline lengthes & $\mathrm{l}(\mathrm{m})$ & $10^{5}$ & 0.012 & $1.2 \times 10^{-7}$ \\
\hline gravity & $\mathrm{g}\left(\mathrm{m} \cdot \mathrm{s}^{-2}\right)$ & 9.81 & 9.81 & 1 \\
\hline densities & \multicolumn{4}{|l|}{$\rho(k g . m-3)$} \\
\hline oceanic lithosphere & $\rho_{\mathrm{s}}$ & 3370 & 1476 & 0.438 \\
\hline Continental lithosphere & $\rho_{\mathrm{c}}$ & 3200 & 1348 & 0.421 \\
\hline mantle & $\rho_{\mathrm{m}}$ & 3300 & 1425 & 0.432 \\
\hline contrast o-m & $\Delta \rho=\rho_{\mathrm{s}}-\rho_{\mathrm{m}}$ & 70 & 51 & 0.729 \\
\hline contrast c-m & $\rho_{\mathrm{c}}-\rho_{\mathrm{m}}$ & -100 & -77 & 0.77 \\
\hline Viscosities & \multicolumn{4}{|l|}{$\eta($ Pa.s $)$} \\
\hline ocean & $\eta_{\mathrm{s}}$ & $2.50 \times 10^{22}$ & 159000 & $6.36 \times 10^{-18}$ \\
\hline continent & $\eta_{\mathrm{c}}$ & $2.50 \times 10^{22}$ & 99500 & $3.98 \times 10^{-18}$ \\
\hline mantle & $\eta_{\mathrm{m}}$ & $10^{20}$ & 459 & $4.59 \times 10^{-18}$ \\
\hline \multicolumn{5}{|c|}{ Deductions from scaling } \\
\hline \multirow{2}{*}{\multicolumn{2}{|c|}{$\begin{array}{l}\text { time } \mathrm{t}=\eta / \sigma=\eta / \rho \mathrm{gl} \\
\text { convergence velocity } \mathrm{u}=\mathrm{l} / \mathrm{t}\end{array}$}} & $\approx 1 \mathrm{My}$ & $1 \mathrm{~h}$ & $1.350 \times 10^{-10}$ \\
\hline & & $\approx 4 \mathrm{~cm} / \mathrm{y}$ & $4.4 \mathrm{~mm} / \mathrm{h}$ & 887 \\
\hline
\end{tabular}

The model set up follows the experimental design of Davy and Cobbold (1991), where lithospheric rheological profile is simulated constructing a brittle (dry sand) -ductile (silicone putty) layered model (Figure 1), resting on top of glucose syrup, which simulates the asthenosphere. Two kinds of sand-silicone cakes, either lighter or denser than the glucose syrup, are used to represent continental or oceanic lithospheres, respectively. The oceanic plate strength is usually larger or similar to that of the continent. The lower boundary of the box (19 cm-deep) approximates a high gradient viscosity transition within the lower mantle 
(see King, 1995 for the data; and Ribe et al., 2007 for effects). The initiation of the oceanic plate subduction beneath the continent has been guided by the formation of a weak-zone determined by the removal of a $1 \mathrm{~cm}$-wide band of sand. Sand is also removed along the lateral boundaries of the box to minimize lateral boundary effects.

Table 2: experiments' parameters. †Dimensionless numbers indicate how the slab is expected to deform (fig. 2; Regard et al. 2003).

\begin{tabular}{|c|c|c|c|c|}
\hline Experiment number & & B08 & B10 & B09 \\
\hline \multicolumn{5}{|c|}{ Thickness $\left(10^{-3} \mathrm{~m}\right)$} \\
\hline Silicon layers & $H_{\text {sil }}$ & 9 & 9 & 9 \\
\hline Sand layers & $H_{\text {sand }}$ & $1-1.5$ & 1.5 & 1 \\
\hline Honey & $H_{m}$ & 180 & 192 & 197 \\
\hline \multicolumn{5}{|c|}{ Lengths $\left(10^{-3} \mathrm{~m}\right)$} \\
\hline Southern continent & $L_{C S}$ & 205 & 240 & 175 \\
\hline Ocean & $L_{o}$ & 100 & 90 & 95 \\
\hline Northern continent & $L_{c n}$ & 200 & 170 & 230 \\
\hline \multicolumn{5}{|c|}{ viscosities ( $\mathrm{Pa}$ s) } \\
\hline Oceanic silicone & $\eta_{o}$ & $1.610^{5}$ & $2.910^{5}$ & $2.910^{5}$ \\
\hline Continental silicone & $\eta_{c}$ & $1.010^{5}$ & $4.010^{5}$ & $4.010^{5}$ \\
\hline Honey & $\eta_{m}$ & $4.610^{2}$ & $4.610^{2}$ & $4.610^{2}$ \\
\hline \multicolumn{5}{|c|}{ densities $\left(\mathrm{kg} \mathrm{m}^{-3}\right)$} \\
\hline Oceanic silicone & $\rho_{o s i l}$ & 1476 & 1488 & 1488 \\
\hline Oceanic sand & $\rho_{\text {osand }}$ & 1500 & 1500 & 1500 \\
\hline Continental silicone & $\rho_{c s i l}$ & 1348 & 1390 & 1410 \\
\hline Continental sand & $\rho_{\text {csand }}$ & 1500 & 1250 & 1500 \\
\hline Honey & $\rho_{m}$ & 1425 & 1430 & 1430 \\
\hline \multicolumn{5}{|c|}{ Time } \\
\hline
\end{tabular}

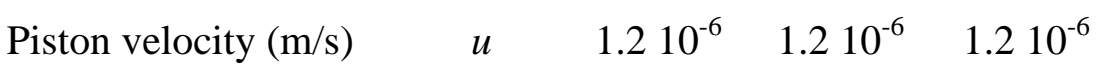

Dimensionless numbers $\dagger$

$\begin{array}{llll}F_{1} & 1.94 & 1.34 & 1.29 \\ F_{2} & 4.33 & 2.91 & 2.88\end{array}$

Models are constructed inside a rectangular Plexiglas tank (50 cm long and $30 \mathrm{~cm}$ wide; Figure 1). Horizontal shortening is imposed by displacement of a rigid piston at constant velocity perpendicular to the plate boundary to mimic the effect of an external push related to 
plate motion. The piston is pushing northward at a constant velocity of $4.4 \mathrm{~mm} / \mathrm{h}$ roughly equivalent to $4 \mathrm{~cm} / \mathrm{y}$ in nature (Table 1 ). For convenience, we will refer thereafter to regions of the experiment in terms of geographical directions, the southern boundary corresponding to the piston. A squared grid of passive sand markers enables the visualization of the surface deformation. Materials parameters, similarity criteria and modeling technique are fully described in Regard et al., (2003).

Experiments have been performed to analyze slab geometry evolution and its style of deformation during break-off. We tested several parameters including the physical parameters of lower-upper plate, velocity and absolute motion of plates, and position of the subduction zone inside the model. Regard et al. (2003) explores the conditions for slab deformation and break off by means of parametric study. Two parameters are defined: $F_{1}$ and $F_{2}$ (fig. 2). Slab break-off is obtained only under a restricted range of parameters, with $F_{1}$ and $F 2$ greater than, respectively, $\sim 1.1$ and $\sim 3$ (Regard et al., 2003). For convenience, we will describe here one experiment (B10) selected as representative to illustrate the process (Table 2).

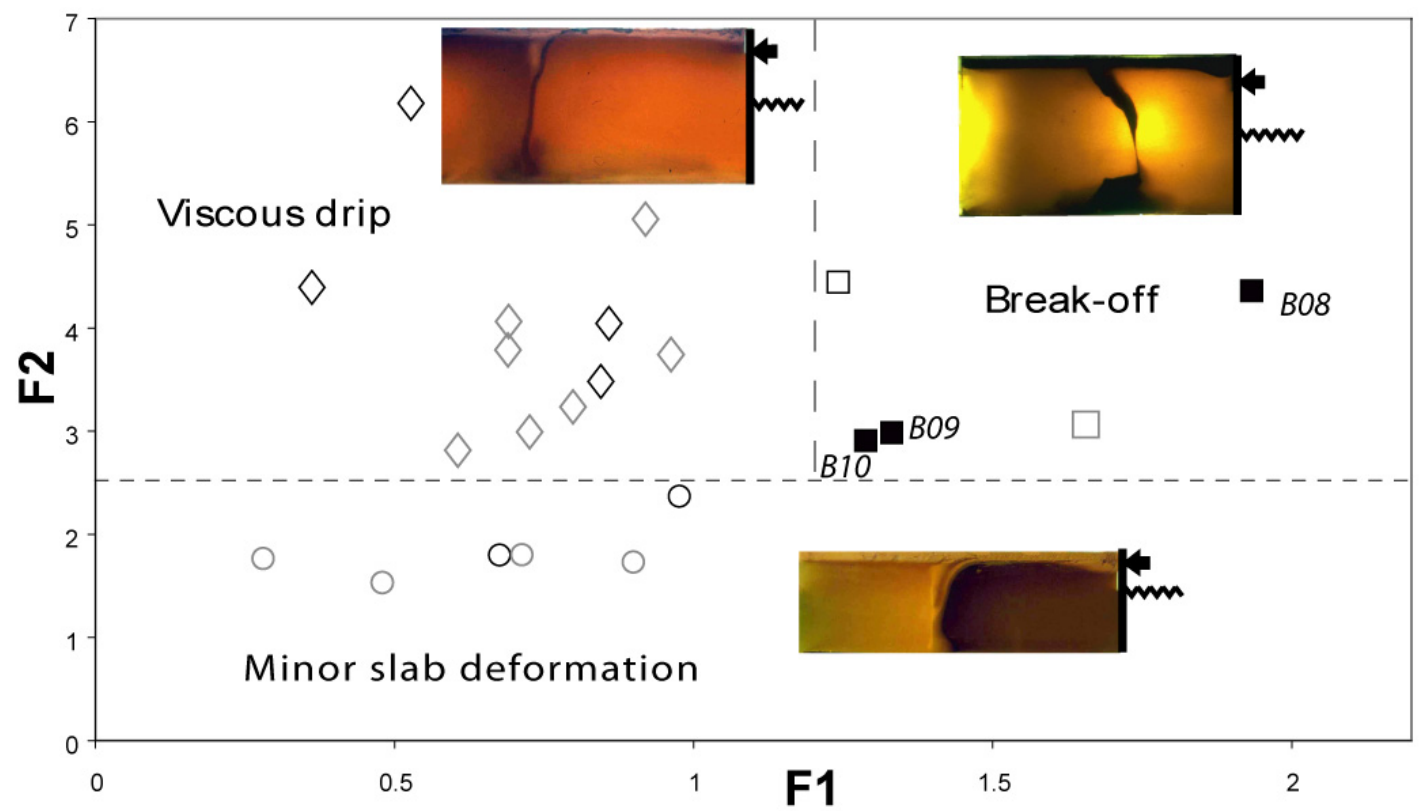

Figure 2. $F_{1}$ and $F_{2}$ dimensionless parameters for this set of experiments (filled symbols) plus those from Regard et al. (2003) and from Regard et al. (2005) in black and grey, respectively. $F_{1}$ characterises the possibility for the slab to break under its own weight: $F_{1}=F_{T} / F_{\text {rupture }}$, where $F_{T}$ and $F_{\text {rupture, }}$ the force necessary to achieve the rupture of the slab. $F_{2}$ characterises the possibility for a viscous instability affecting the oceanic slab to develop before the slab reaches the bottom of the convective layer; $F_{2}$ is the ratio between two characteristic times, $t_{1}$, the characteristic time for the tip of the slab to reach the bottom of the low-viscosity mantle and $t_{2}$, the time necessary to achieve the formation of a viscous instability (Regard et al., 2003). The graph is divided in three parts corresponding to different slab behaviours defined in previous experiments (Regard et al., 2003; Regard et al., 2005). 


\section{$2 \quad$ Experimental results}

\section{Experiment B10}

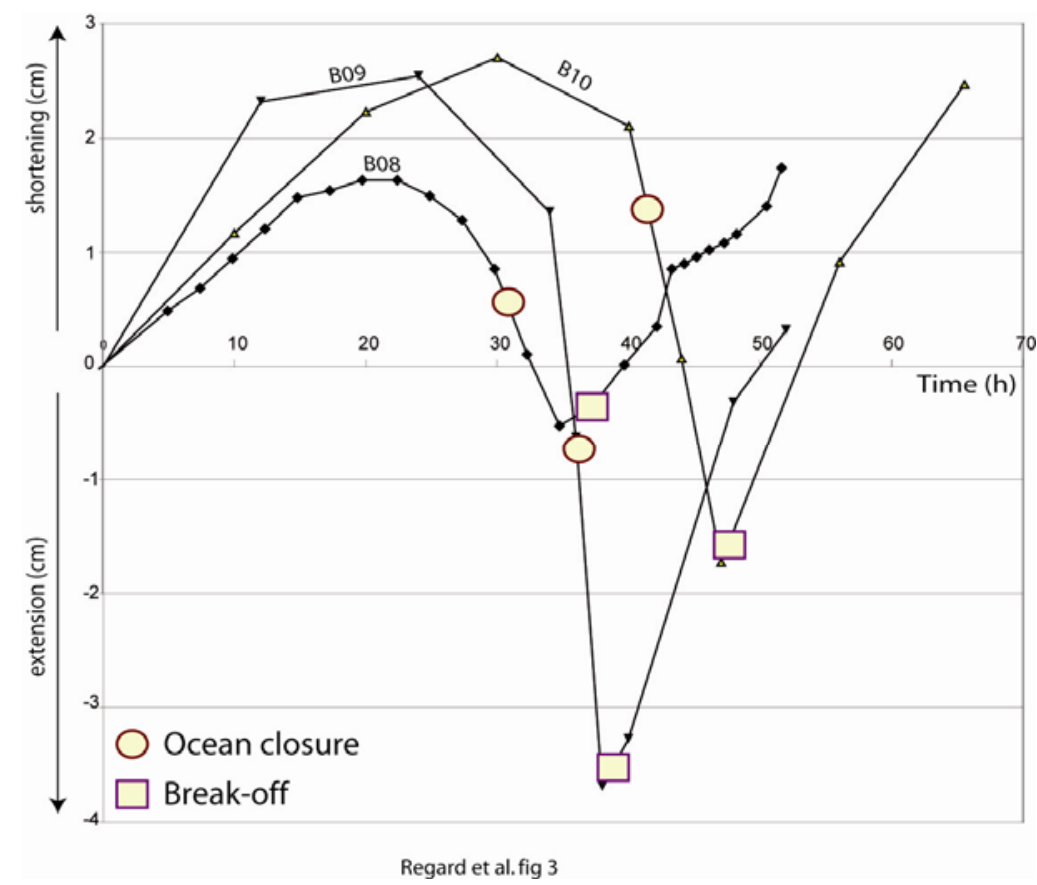

Figure 3. Upper plate surface shortening for the three experiments.

The evolution of experiment B10 begins by a first stage of subduction initiation (fig. 3). That period of subduction initiation is characterized by the formation of compressive superficial structures, illustrating the difficulty to initiate a subduction zone. This has been described in details in Faccenna et al. (1999) and Regard et al. (2003). Mature subduction initiates after 30 hours of experiment; during this period the slab-pull is larger, causing extensional superficial deformation (i.e., the subduction velocity is greater than the piston velocity on the upper plate, fig. 3). The dip of the slab is steeply dipping towards the advancing continent (figs. 4 \& 5). The entire oceanic plate is subducted after 42 hours, and when the continent starts subducting at trench. From this moment slab started stretching and finally broke after roughly 47-48 hours (fig. 4). The rupture is approximately localized at the continent-ocean margin that separates the heavy (oceanic) lower part from the upper lighter part of the slab. Because of the Newtonian silicone rheology, the complete rupture is achieved by a progressive stretching and thinning of the slab. The broken portion of the slab sinks and then lies down on the bottom of the box, preserving the same dip-direction. Meanwhile, the pending portion of the slab reverses its dip-direction, teared by the broken part of the slab as well as by the induced mantle circulation (figs. 5 \& 6). After the break-off, the surface tectonic regime changes drastically and collision starts (fig. 3). 
$38 \mathrm{~h}$

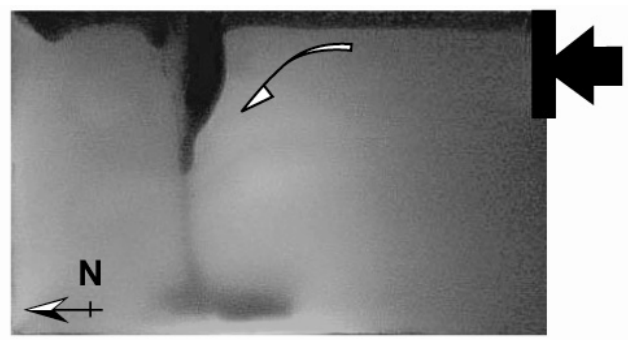

$43 \mathrm{~h}$

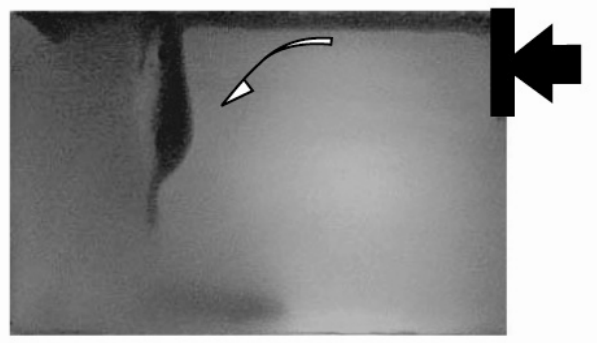

$46 \mathrm{~h}$

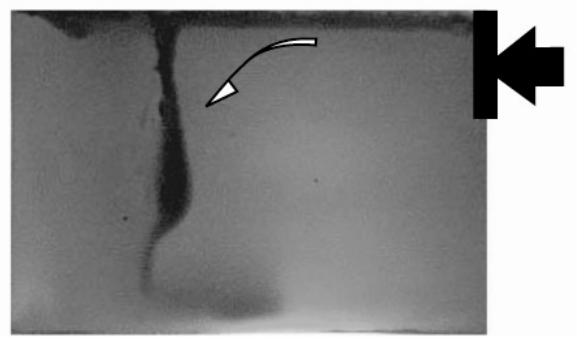

$47 \mathrm{~h}$

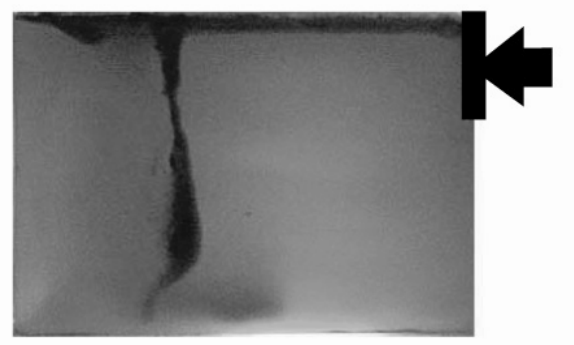

$48 \mathrm{~h}$

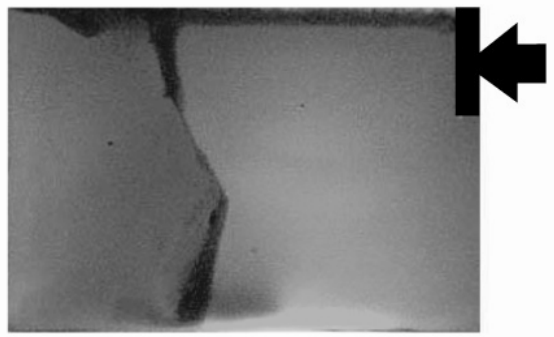

Regard et al., fig 4

$50 \mathrm{~h}$

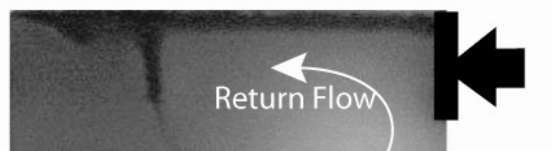

Slab tilt

and

induced flow

Figure 4. Lateral views of experiment B10during break-off, after 38, 43, 46, 47, 48, and $50 \mathrm{~h}$ of experimental run. The break-off itself occurs between 47 and $48 \mathrm{~h}$ after a progressive thinning and necking of the slab at oceanic-continental boundary. The broken portion of the slab sinks down to the bottom of the box while the upper pending part of the slab reverses its dip. The mantle likely flows following the drawn arrows. 


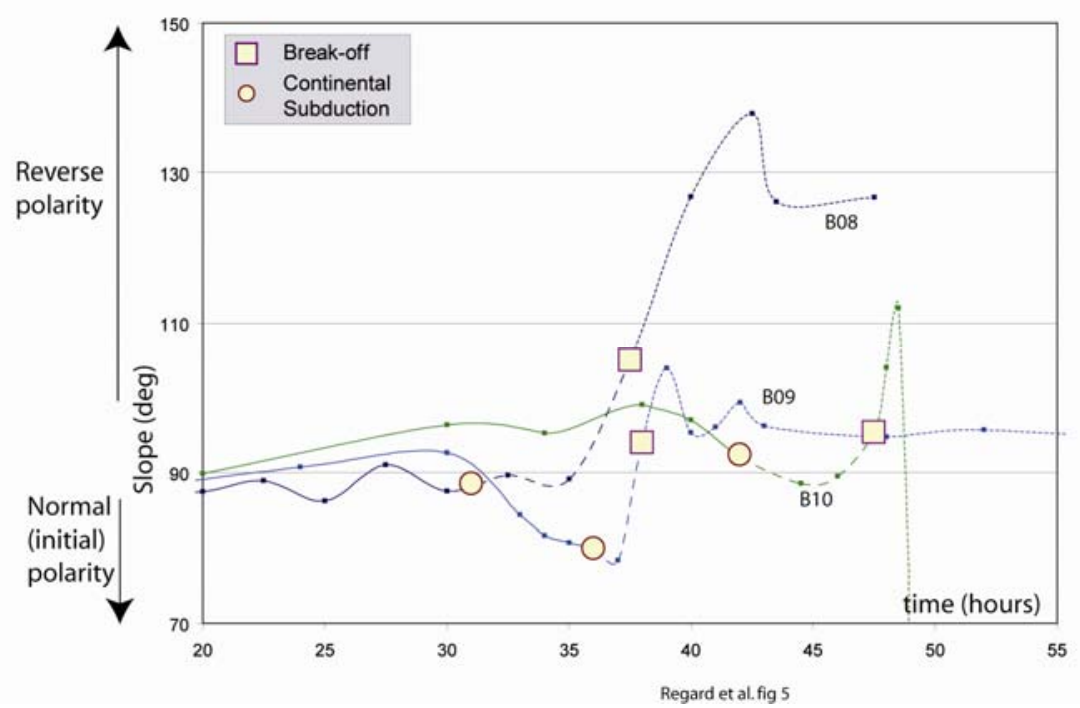

Figure 5. Slab dip vs. time for the three experiments. Dip value is an average over the first 3 centimeters under the plates; values lower than 90 degrees indicate the dip-direction is the initial one, northward for experiments B10 and B08 and southward for experiment B09. Values higher than 90 degrees denote slab dip reversal.

Figure 6 shows three snapshots of slab rupture for three different experiments (experiments B08, B09 and B10 see table 2), regardless of the initial polarity of the subduction zone and of the absolute motion of the subducting oceanic plate (fig. 5 and 6). Despite the initial dip of the slab is always sub-vertical, the rupture of the slab is marked by a rapid (about 2-5 hours) change in both slab dip and dip-direction (Figure 5). The slab initial sub-vertical behaviour is always observed in our experimental setup before slab interaction with the box bottom boundary (Faccenna et al., 1996; Becker et al., 1999; Regard, 2003), due to the low slab strength.

In all the experiments, break-off occurs after continental subduction at the continent-ocean boundary. It separates the upper light part from the lower dense part of the slab and the mechanism of dip reversal is always similar to the one described before. 

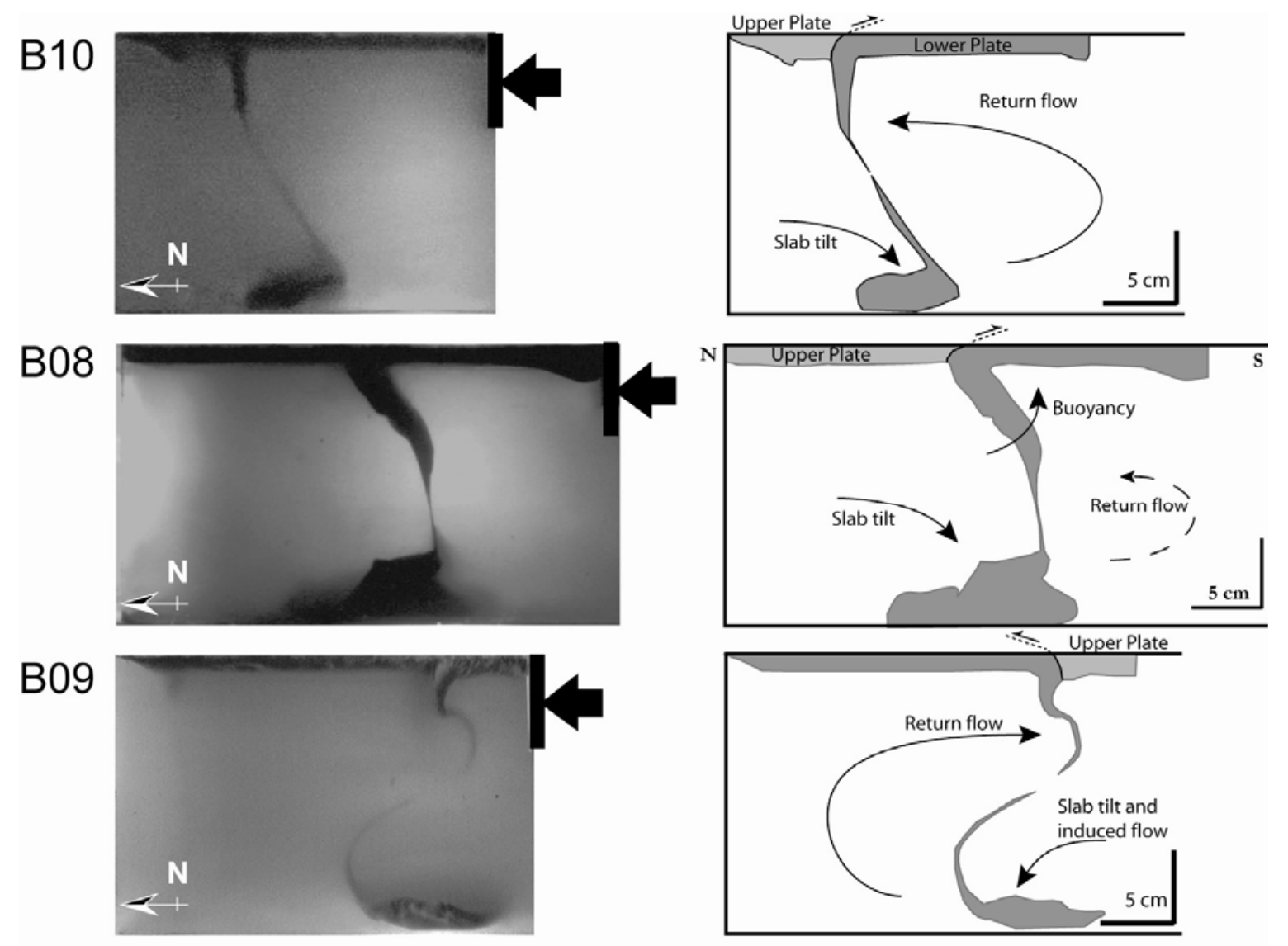

Regard et al., fig. 6

Figure 6. Lateral views and interpretative drawings of experiments just after break-off. The oceanic plate was initially subducting northward for exp. B10 and B08, southward for exp B09. All the experiments show a subduction dip reversal after break-off, from north-dipping to south dipping for B08 and B10 and conversely, from south to north-dipping for B09.

\section{Discussion}

The application of the experimental result in a natural system is of course limited by the oversimplified experimental setting and by the assumptions used to build up the model. However, some characteristics of the experiments can be used to interpret the evolution of some mountain belts. Generally, slab break-off is manifested and recognized on the surface by the following geological signatures:

- Uplift of the upper plate (e.g., Buiter et al., 2002; Rogers et al., 2002; Gerya et al., 2004). This is commonly viewed as a result of the isostatic rebound after break-off and unloading of the subducted plate. Uplift, in turn, favors extension in the inner and higher portion of the orogenic belt, and increases the erosion rate that can be registered by deposition in the fore deep domain. 
- Heating of the upper plate. This surge of heat likely produces magmatism and Barrovian metamorphism (HT/LP) and has been related to the inflow of sub-slab mantle material inside the subduction zone (von Blanckenburg and Davies, 1995).

Our experiments cannot reproduce the change in thermal state of the back-arc region, but they can underline some simple mechanical aspect of slab break-off:

1- Slab break-off systematically occurs after continental subduction initiation, separating the dense (pulling downward) "oceanic" part of the subducting plate from its upper buoyant part, pulling upward of the slab. The tension resulting from the buoyancy of the slab is thus maximal at the boundary between the oceanic and continental parts. Similar conclusion has been reached by analytical and numerical studies (Molnar and Gray, 1979; Chemenda et al., 1995; Davies and von Blanckenburg, 1995; e.g., Chemenda et al., 1996; Wong A Ton and Wortel, 1997; Pysklywec et al., 2000; Ranalli et al., 2000; Pysklywec, 2001; Li et al., 2002; Regard et al., 2003; Gerya et al., 2004; Toussaint et al., 2004; Regard et al., 2005).

2 - Slab break-off results in a transient episode of reversal of the subduction dip. Previous numerical simulations of slab deformation and break-off (Pysklywec et al., 2000; Pysklywec, 2001) already suggested that subduction dip reversal is, indeed, likely to occur when the slab breaks. In our experiments, this process is induced by the sinking of the detached portion of the slab in the mantle. While falling into the mantle, the detached portion preserves its initial dip, causing directly (pulling) or indirectly (exciting small scale mantle convection) an episode of slab dip reversal. In particular, this process is also generated by the fact that the rheology of the experimental lithospheric mantle is Newtonian, producing a progressive necking of the slab during break-off. The application of this mechanism to natural system could be limited by the fact that the natural slab rheology is thought to be non-linear with an elasto-plastic component, and possibly stronger than the one simulated here.

\section{Application to the Alps}

These two observations stimulate to look for places where this process may have occurred. Since the late '80, the Alpine belt and the Mediterranean Domain have been considered as a test site to look at the deformation induced by slab break-off following continental subduction. Von Blanckenburg and Davies (1995) first interpreted the Barrovian metamorphism, the reset of the thermochronological data, large magma effusion and change from basaltic to granitic magmatism occurring at about 29-34 Ma as a result of decompression subsequent to slab break-off. Following this idea, the transition from deep marine (flyschs) to continental (molasses) sedimentation, i.e. from underfilled to filled foreland basins, has been 
interpreted as the result of an uplift occurring between 33 and $30 \mathrm{Ma}$, in relation with the slab break-off (Sinclair, 1997). Wortel and Spakman (2000) and Piromallo and Faccenna (2004) proposed that the cold material, observed on tomographic images, lying above the transition zone under the Alps belongs to the formerly subducted Tethys plate (Fig. 7). Taking into account the plate kinematic parameters given by Dewey et al. (1989), Piromallo and Faccenna (2004) determined an age of 30-35 Ma for the slab break-off.
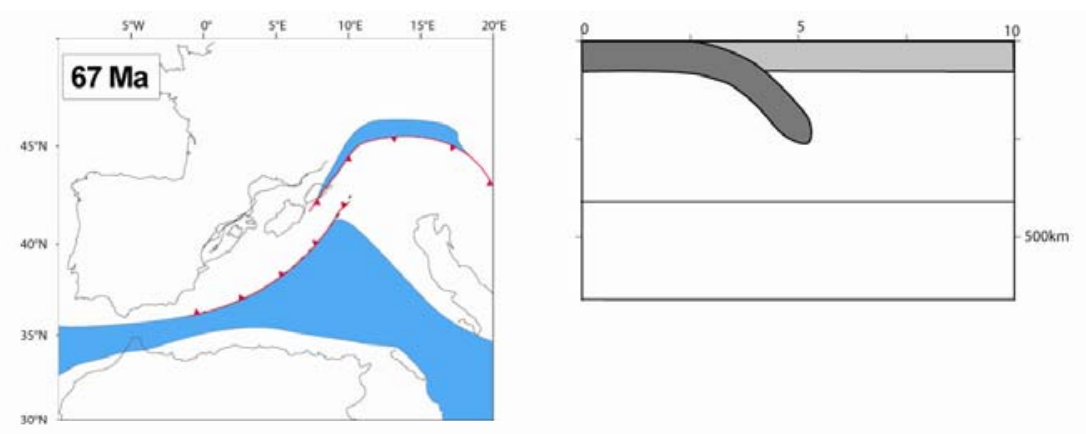

Regard et al.Fig 7
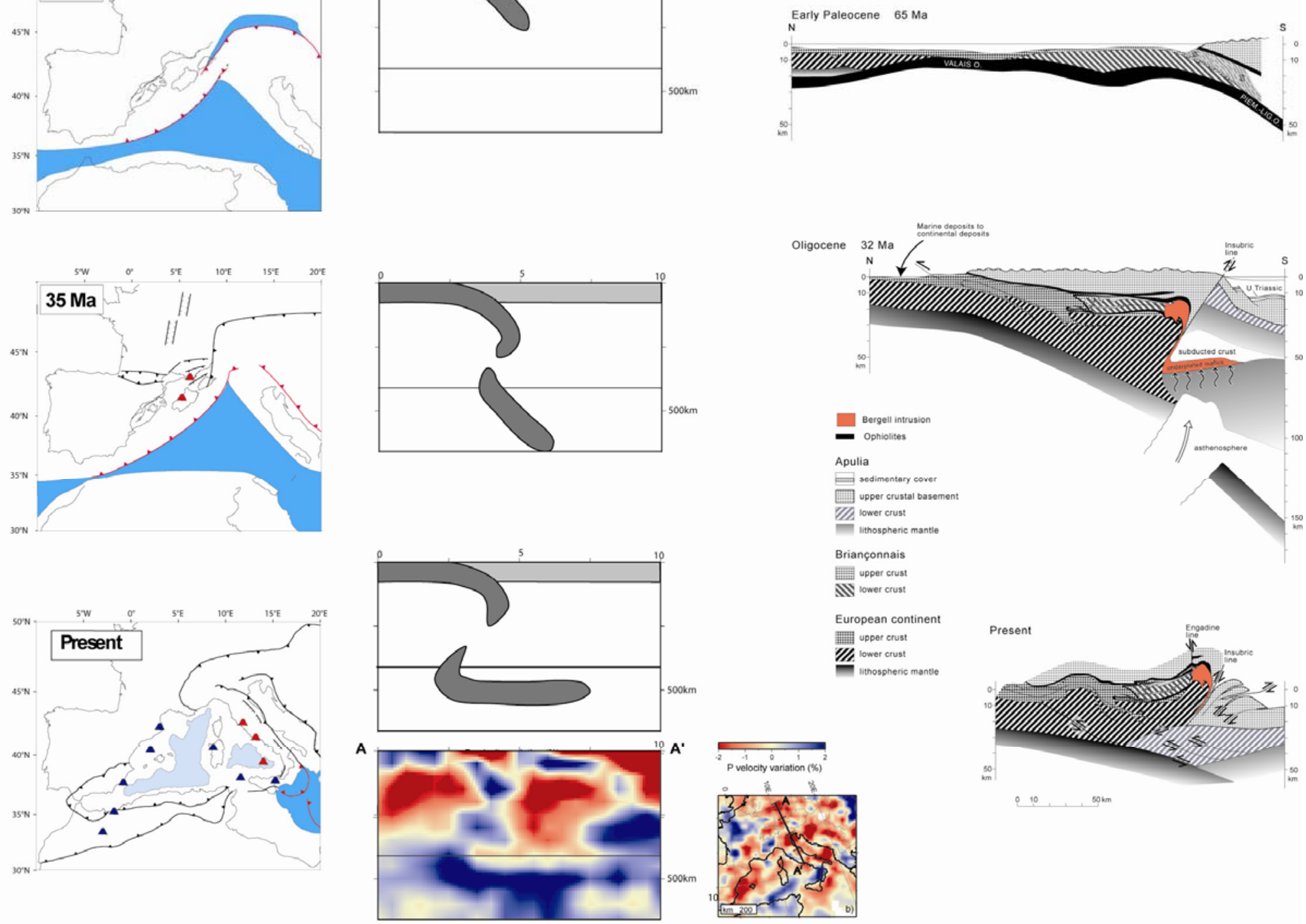

Figure 7. Alpine evolution since 65Ma. Left: palinspatic evolution (Jolivet et al., 2003). Right: balanced sketches of the central Alps (simplified after Schmid et al., 1996; simplified after Schmid et al., 2004), highlighting some effects likely caused by break-off and discussed within the text. Center: schematic plate evolution for 65 and 35 My and a tomography as corresponding modern case (Piromallo and Faccenna, 2004): it shows a Z-shaped highvelocity anomaly, likely representing the sunk Eurasian lithosphere. 
The evolving scenario of the central alpine chain (fig. 7) is then here interpreted as a result of oceanic subduction up to 50 Ma followed by continental consumption and slab break off at about 30-35 Ma (Schmid et al., 1996; Schmid et al., 2004). In fact, a major phase of thrusting accompanied by high-pressure metamorphism occurred at 35 Ma (at the Eocene-Oligocene boundary) in a wide alpine domain (Valais, Briançonnais and Internal Crystalline Massifs, i.e., (Schmid et al., 1996). It included the formation of the Insubric Line (or Periadriatic Line) and development of neoformed backthrusting structures (Pfiffner et al., 2002), testifying for the double vergence of the Alps (Schmid et al., 1996). Moreover, the erosion and exhumation rates increased at the same time (Schlunegger and Willett, 1999; Kuhlemann et al., 2002) and could be due to the pop up of the central Alps between pro- and retro-thrusts (Sinclair and Allen, 1992).

Therefore, at about 35-30 Ma, the alpine wedge is totally reshaped with an overall change in thrust vergence (emplacement of the double vergence). In the light of our experimental data, we propose that this can result from the slab dip reversal subsequent to the slab break-off we reported. This model can independently be supported by tomographic images, showing a Zshaped detached slab with large body of high velocity material stagnating over the $660 \mathrm{~km}$ discontinuity (Fig. 7). In addition, in central-Eastern Alps, high resolution tomographic images show that the reverse dip of the slab is actually still preserved (Lippitsch et al., 2003). Slab break-off under the Alps could have finally propagated westwards, as shown by previous 3D laboratory experiments (Regard et al., 2005), favoring roll-back and initiation of backarc extension in the Western Mediterranean region. If this model is correct, we should then expect that a deep process like slab rupture could be best dated by a transient change in the transport direction of the growing collisional belt.

However, the subduction dip reversal could result from a rupture of the slab (Teng et al., 2000, this study), or not (Tao and O'Connell, 1992; see the models of Pysklywec, 2001). Our experiments suggest that subduction dip reversal (i) is favored by a strong viscous coupling at subduction zone, as Tao and O’Connell (1992) already proposed; (ii) is easier if the dip of the slab is large, or if the rupture within the upper mantle is shallow, to minimize the horizontal displacements of the remaining uppermost slab. Finally, we should consider that our experimental result did not include the rheological and density layering of the continental lithosphere. 
This study reports the result of laboratory experiments where we analyzed the deformation of silicone-sand slab falling into a mantle. Our study shows that the slab can break after the entrance in subduction of a light continental plate and this process marks the onset of collision. In our experiments, slab break-off is accompanied by a transient stage (lasting few million years) of dip reversal. In nature, this could produce a complete re-shaping of the growing collisional wedge, and, eventually, a slab polarity reversal (Faccenda et al.).

We speculate that the dramatic change in the tectonics of the central Alps observed at $\sim 35 \mathrm{Ma}$, with the formation of the Insubric Line and retro-wedge thrusting, could represent the surface expression of a transient episode of slab dip reversal produced by the rupture of the slab at depth (von Blanckenburg and Davies, 1995).

\section{Aknowledgements}

This work was founded by DyETI subduction program. The experiments were conducted in the Roma tre laboratory with many help from F. Funiciello; we thank three anonymous reviewers who made us improve our manuscript and S. Bensmihen for English language correction.

\section{References}

Becker, T. W., Faccenna, C., and O'Connel, R. J. (1999). The development of slabs in the upper mantle: insights from numerical and laboratory experiments. J. of Geoph. Res. 104, 15,207-15,227.

Buiter, S. J. H., Govers, R., and Wortel, M. J. R. (2002). Two-dimensional simulations of surface deformation caused by slab detachments. Tectonophysics 354, 195-210.

Buiter, S. J. H., Wortel, M. J. R., and Govers, R. U. R. (1998). The role of subduction in the evolution of the Apennines foreland basin. Tectonophysics 296, 249-268.

Châtelain, J.-L., Molnar, P., Prévot, R., and Isacks, B. (1992). Detachment of part of the downgoing slab and uplift of the new Hebrides (Vanuatu) islands. Geoph. Res. Lett. 19, $1,507-1,510$.

Chemenda, A. I., Mattauer, M., and Bokun, A. N. (1996). Continental subduction and a mechanism for exhumation of high pressure metamorphic rocks: new modelling and field data from Oman. Earth Planet. Sci. Lett. 143, 173-182.

Chemenda, A. I., Mattauer, M., Malavieille, J., and Bokun, A. N. (1995). A mechanism for syn-collisional deep rock exhumation and associated normal faulting: results from physical modelling. Earth Planet. Sci. Lett. 132, 225-232.

Davies, J. H., and von Blanckenburg, F. (1995). Slab break-off: a model of lithosphere detachment and its test in the magmatism and deformation of collisional orogens. Earth and Planet. Sc. Lett. 129, 85-102.

Davy, P., and Cobbold, P. R. (1991). Experiments on shortening of a 4-layer model. Tectonophysics 188, 1-25. 
Dewey, J. F., Helman, M. L., Turco, E., Hutton, D. H. W., and Knott, S. D. (1989).

Kinematics of the western Mediterranean. Alpine tectonics, Published by Blackwell Scientific; Geological Society Special Publication, 45, Editors Coward M.P. and et al., 265.

Faccenda, M., Gerya, T. V., and Chakraborty, S. Styles of post-subduction collisional orogeny: Influence of convergence velocity, crustal rheology and radiogenic heat production. Lithos In Press, Corrected Proof.

Faccenna, C., Bellier, O., Martinod, J., Piromallo, C., and Regard, V. (2006). Slab detachment beneath eastern Anatolia: A possible cause for the formation of the North Anatolian fault. Earth and Planetary Science Letters 242, 85.

Faccenna, C., Davy, P., Brun, J.-P., Funiciello, R., Giardini, D., Mattei, M., and Nalpas, T. (1996). The dynamics of back-arc extension: an experimental approach to the opening of the Tyrrhenian Sea. Geophys. J. Int. 126, 781-795.

Faccenna, C., Giardini, D., Davy, P., and Argentieri, A. (1999). Initiation of subduction at Atlantic-type margins: insights from laboratory experiments. J. Geophys. Res. 104, 2,749-2,766.

Gerya, T. V., Yuen, D. A., and Maresch, W. V. (2004). Thermomechanical modelling of slab detachment. Earth and Planetary Science Letters 226, 101.

Jolivet, L., Faccenna, C., Goffe, B., Burov, E., and Agard, P. (2003). Subduction tectonics and exhumation of high-pressure metamorphic rocks in the Mediterranean orogens. American Journal of Science 303, 353-409.

Keskin, M. (2003). Magma generation by slab steepening and breakoff beneath a subductionaccretion complex: An alternative model for collision-related volcanism in Eastern Anatolia, Turkey. Geophys. Res. Lett. 30, 8046, doi:10.1029/2003GL018019.

King, S. D. (1995). Models of mantle viscosity. In "Mineral Physics, and Crystallography, AGU Ref. Shelf 2." (T. J. Ahrens, Ed.), pp. 227-236. AGU, Washington, D.C.

Kuhlemann, J., Frisch, W., Szekely, B., Dunkl, I., and Kazmer, M. (2002). Post-collisional sediment budget history of the Alps: tectonic versus climatic control. International Journal Of Earth Sciences 91, 818-837.

Li, L. G., Liao, X. H., and Fu, R. S. (2002). Slab breakoff depth: A slowdown subduction model. Geophysical Research Letters 29.

Lippitsch, R., Kissling, E., and Ansorge, J. (2003). Upper mantle structure beneath the Alpine orogen from high-resolution teleseismic tomography. Journal Of Geophysical Research-Solid Earth 108.

Molnar, P., and Gray, D. (1979). Subduction of continental lithosphere: Some constraints and uncertainties. Geology 7, 58-62.

Pfiffner, O. A., Schlunegger, F., and Buiter, S. J. H. (2002). The Swiss Alps and their peripheral foreland basin: Stratigraphic response to deep crustal processes. Tectonics 21.

Piromallo, C., and Faccenna, C. (2004). How deep can we find the traces of Alpine subduction? Geophysical Research Letters 31.

Pysklywec, R. N. (2001). Evolution of subducting mantle lithosphere at a continental plate boundary. Geophysical Research Letters 28, 4399-4402.

Pysklywec, R. N., Beaumont, C., and Fullsack, P. (2000). Modeling the behaviour of the continental mantle lithosphere during plate convergence. Geology 28, 655-658.

Ranalli, G., Pellegrini, R., and D'Affizi, S. (2000). Time dependance of negative buoyancy and the subduction of continental lithosphere. J. Geodyn. 30, 539-555.

Regard, V. (2003). "Lateral and temporal evolution from subduction to collision: insights from Iranian tectonics (Zagros-Makran) and physical modeling (in French and English)." Univ. Aix-Marseille III. 
Regard, V., Faccenna, C., Martinod, J., and Bellier, O. (2005). Slab pull and indentation tectonics: insights from 3D laboratory experiments. Physics of the Earth and Planetary Interiors 149, 99-113.

Regard, V., Faccenna, C., Martinod, J., Bellier, O., and Thomas, J. C. (2003). From subduction to collision: Control of deep processes on the evolution of convergent plate boundary. Journal of Geophysical Research-Solid Earth 108, 2208, doi:10.1029/2002JB001943.

Ribe, N. M., Stutzmann, E., Ren, Y., and van der Hilst, R. (2007). Buckling instabilities of subducted lithosphere beneath the transition zone. Earth and Planetary Science Letters 254, 173.

Rogers, R. D., Karason, H., and van der Hilst, R. D. (2002). Epeirogenic uplift above a detached slab in northern Central America. Geology 30, 1031-1034.

Schlunegger, F., and Willett, S. D. (1999). Spatial and temporal variations in exhumation of the Central Swiss Alps and implications for exhumation mechanisms. In "Exhumation processes: normal faulting, ductile flow, and erosion." (M. Brandon, and S. D. Willett, Eds.), pp. 157-180. Geological Society of London Special Publication.

Schmid, S. M., Fügenschuh, B., Kissling, E., and Schuster, R. (2004). TRANSMED Transects IV, V and VI: Three lithospheric transects across the Alps and their forelands. In "The TRANSMED Atlas: The Mediterranean Region from Crust to Mantle." (W. Cavazza, F. Roure, W. Spakman, G. M. Stampfli, and P. A. Ziegler, Eds.). Springer Verlag.

Schmid, S. M., Pfiffner, O. A., Froitzheim, N., Schönborn, G., and Kissling, E. (1996). Geophysical-geological transect and tectonic evolution of the Swiss-Italian Alps. Tectonics 15, 1036-1064.

Sinclair, H. D. (1997). Flysch to molasse transition in peripheral foreland basins: The role of the passive margin versus slab breakoff. Geology 25, 1123-1126.

Sinclair, H. D., and Allen, P. A. (1992). Vertical versus horizontal motions in the Alpine orogenic wedge: stratigraphic response in the foreland basin. Basin Research 4, 215 232.

Tao, W. C., and O'Connell, R. J. O. (1992). Ablative subduction: a two-sided slternative to the conventional subduction model. J. Geoph. Res. 91, 8877-8904.

Teng, L. S., Lee, C. T., Tsai, Y. B., and Hsiao, L. Y. (2000). Slab breakoff as a mechanism for flipping of subduction polarity in Taiwan. Geology 28, 155-158.

Toussaint, G., Burov, E., and Jolivet, L. (2004). Continental plate collision: Unstable vs. stable slab dynamics. Geology 32, 33-36.

von Blanckenburg, F., and Davies, J. H. (1995). Slab breakoff: A model for syncollisional magmatism and tectonics in the Alps. Tectonics 14, 120-131.

Wong A Ton, S. Y. M., and Wortel, M. J. R. (1997). Slab detachment in continental collision zones: an analysis of controlling parameters. Geoph. Res. Lett. 24, 2,095-2,098.

Wortel, M. J. R., and Spakman, W. (1992). Structure and dynamics of subducted lithosphere in the Mediterranean region. Proc. Kon. Ned. Akad. v. Wetensch. 95, 325-347.

Wortel, M. J. R., and Spakman, W. (2000). Subduction and slab detachment in the Mediterranean-Carpathian region. Science 290, 1910-1917. 